\title{
Objectively measured patient cooperation during early orthodontic treatment: Does psychology have an impact?
}

\author{
Michał Sarul ${ }^{11, A-F}$, Bianka Lewandowska ${ }^{2, A, C, D}$, Beata Kawala1, E, Anna Kozanecka, ${ }^{1, B}$, Joanna Antoszewska-Smith ${ }^{1, A, E, F}$ \\ ${ }^{1}$ Department of Dentofacial Orthopedics and Orthodontics, Wroclaw Medical University, Poland \\ ${ }^{2}$ Institute of Psychology, Faculty of Pedagogical and Historical Sciences, University of Wrocław, Poland \\ A - research concept and design; $\mathrm{B}$ - collection and/or assembly of data; $\mathrm{C}$ - data analysis and interpretation; \\ $D$ - writing the article; $E$ - critical revision of the article; $F$ - final approval of the article
}

Address for correspondence

Michał Sarul

Email:michal.sarul@gmail.com

Funding sources

None declared

Conflict of interest

None declared

Received on February 27, 2016

Reviewed on June 6, 2016

Accepted on 0ctober 6, 2016

\section{Abstract}

Background. The effectiveness of orthodontic treatment with removable appliances arouses controversy concerning the level of patients' compliance. The compliance depends on factors controlled by the orthodontists, by the patients themselves and by their caregivers, and those beyond any control.

Objectives. The purpose of this study was to assess the extent to which the personality traits of patients and their caregivers affect the cooperation in removable appliance therapy.

Material and methods. A total of 38 patients (19 boys, 19 girls) aged 9-12 years, presenting malocclusions suitable for removable appliance therapy were randomly selected. The EAS-C Temperament Questionnaire, Generalized Self-Efficacy Scale, NE0-Five Factor Inventory and Parental Attitude Scale developed by Plopa were employed to evaluate the patients' and the caregivers' temperamental dispositions. Electronic sensors were employed to objectively assess patients' cooperation.

Results. Statistical analysis revealed a high positive correlation between removable appliance wear time and the results of the GSES and the SPR-R, a strongly positive correlation between wear time and the NEOFFI-C results and a strongly negative correlation between wear time and the EAS-C-Emo measurement. The level of a generalized sense of efficacy, conscientiousness and the severity of requirements imposed on the child were the factors related to the caregivers, positively correlating with patients' cooperation.

Conclusions. The cooperation of children treated with removable appliances may be foreseen with observation of the patients' and their caregivers' traits. Objective evaluation of the patients' cooperation and psychological tests may be valuable tools for the re-assessment of the paradigm of early orthodontic treatment.

Key words: patient compliance, orthodontics, removable appliances

DOI

10.17219/acem/65659

Copyright

Copyright by Author(s)

This is an article distributed under the terms of the

Creative Commons Attribution Non-Commercial License

(http://creativecommons.org/licenses/by-nc-nd/4.0/) 


\section{Introduction}

According to various epidemiological studies, malocclusions affect approx. 20-93\% of the population..$^{1,2}$ Analyses based on the NHANES III survey, one of the most often cited studies, show that about $2 / 3$ of the population is battling against some form of abnormal occlusion. Given these numbers, it seems reasonable to say that malocclusions are very common disorders. ${ }^{3}$ It is therefore not surprising that in many countries orthodontic treatment costs are covered by the insurance fund, however an objective reimbursement requires establishing and developing consistent, uniform procedures for the most effective treatment of malocclusions.

In early and interceptive treatment, removable dental appliances such as plates and, most often, functional appliances, are frequently used. Many clinicians apply them during the retention period following the active phase of orthodontic treatment with fixed appliances. Orthodontic treatment with removable appliances arouses controversy because of 2 aspects: (1) the need to achieve an adequate level of patient compliance; and (2) contradictory results of the analyses on the effectiveness of such treatment. ${ }^{4-8}$

Patient compliance may depend on many factors. Some of them are controlled by the orthodontists, some by the patients themselves and their caregivers, and some of them are beyond any control. Regularity and daily appliance-wearing time may therefore depend on the child's character traits, the parents' specific dispositions and the nature of their conduct. ${ }^{8}$ According to several authors, wearing a removable appliance is prohealth behavior, which over time may become a habit; however, at the beginning of treatment it requires a high level of monitoring and commitment on the part of caregivers supervising the child's behavior. ${ }^{8}$

As for fully-objective monitoring of a daily appliancewearing, it was, for many years, technically impossible. It affected not only clinical procedures, but also reliability; patient compliance could have a substantial impact on the results of various studies on the effectiveness of removable appliances, thus likely influencing treatment strategies. ${ }^{4}$ It was not until recently that this problem was solved as the emergence of electronic systems for checking patients' compliance has finally helped assess the real daily appliance-wearing time.

Subsequently, one of the key questions arises: Is it possible to predict the degree of patients' compliance in orthodontic treatment before it begins? Therefore, the purpose of our work was to assess the extent to which the personality traits of patients and their caregivers correlate with the actual degree of cooperation in orthodontic treatment with removable appliances. Based on the literature, it was assumed that the formal features of the child's temperament may be decisive when it comes to adopting a new pro-health attitude. ${ }^{8-12}$ It was also assumed that the effectiveness of motivating a child to systematically wear a removable appliance may depend on the caregivers' dispositions such as a strong sense of self-efficiency, personality dispositions and parental attitudes.

\section{Material and methods}

\section{Material}

A group of 202 randomly selected patients were examined. Finally, 38 patients (19 boys and 19 girls) meeting the following inclusion criteria (Fig. 1) participated in the study:

- age 9-12 years;

- generally healthy, no syndromes or clefts;

- malocclusion likely to improve by means of active plate or twin block: light to moderate crowding in the upper front area, class II functional shift, pseudo class III, bilateral cross-bite due to narrow upper dental arch.

Fig. 1. Consort flow diagram of the study

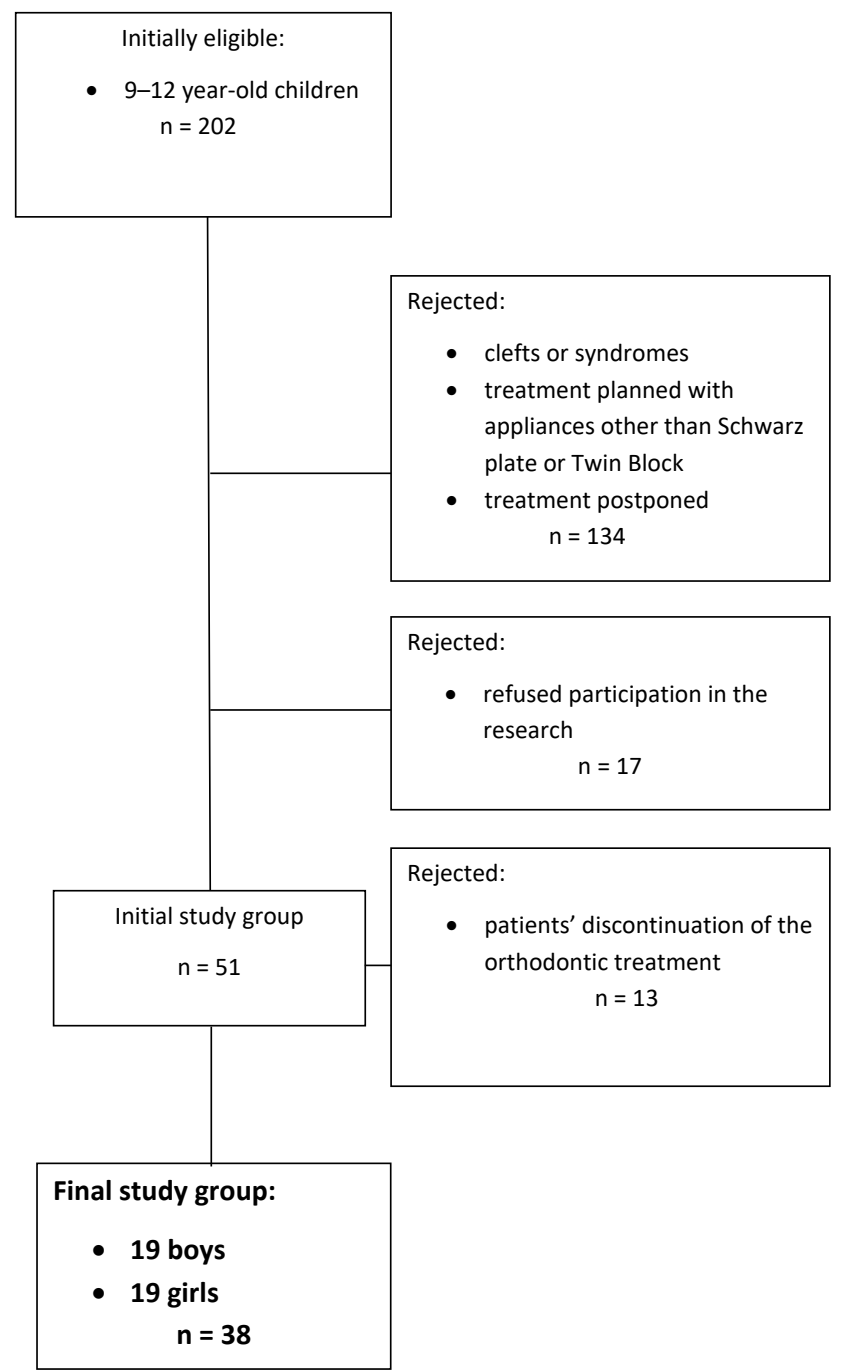




\section{Methods}

All patients' and their caregivers' personality traits were psychologically tested by the same psychologist (B.L.). The suitable questionnaires (Table 1) were filled prior to the beginning of treatment.

Table 1. Description of tests used

\begin{tabular}{|c|c|c|}
\hline Test & Description & Range \\
\hline GSES & $\begin{array}{l}\text { level of a generalized sense } \\
\text { of efficacy in the parent involved } \\
\text { in implementing the set } \\
\text { of recommendations }\end{array}$ & $\begin{array}{l}\text { the range that } \\
\text { may be obtained } \\
\text { is } 10-40 \text { points, } \\
\text { the higher the score, } \\
\text { the stronger } \\
\text { the disposal }\end{array}$ \\
\hline Neo-FFIN & $\begin{array}{l}\text { basic parent personality trait: } \\
\text { neuroticism }\end{array}$ & \multirow{5}{*}{$\begin{array}{l}\text { for each } \\
\text { of the subscales, } \\
\text { the result can be } \\
\text { a value of } 0-48 \text {, } \\
\text { the higher it is, } \\
\text { the greater } \\
\text { the severity } \\
\text { of the measured trait }\end{array}$} \\
\hline Neo-FFIE & $\begin{array}{l}\text { basic parent personality trait: } \\
\text { extraversion }\end{array}$ & \\
\hline Neo-FFIO & $\begin{array}{l}\text { basic parent personality trait: } \\
\text { openness to experience }\end{array}$ & \\
\hline Neo-FFI A & $\begin{array}{l}\text { basic parent personality trait: } \\
\text { agreeableness }\end{array}$ & \\
\hline Neo-FFIC & $\begin{array}{l}\text { basic parent personality trait: } \\
\text { conscientiousness }\end{array}$ & \\
\hline EAS-C-Emo & $\begin{array}{l}\text { patients' temperamental } \\
\text { dispositions understood } \\
\text { as inherited personality } \\
\text { traits: children's tendency } \\
\text { to experience emotions intensely }\end{array}$ & \multirow{4}{*}{$\begin{array}{l}\text { for each } \\
\text { of the subscales, } \\
\text { the result may be } \\
\text { a value of } 5-25, \\
\text { the higher it is, } \\
\text { the higher } \\
\text { the severity } \\
\text { of the measured trait }\end{array}$} \\
\hline EAS-C-Act & $\begin{array}{l}\text { patients' temperamental } \\
\text { dispositions understood } \\
\text { as inherited personality traits: } \\
\text { activity }\end{array}$ & \\
\hline EAS-C-Soc & $\begin{array}{l}\text { patients' temperamental } \\
\text { dispositions understood } \\
\text { as inherited personality traits: } \\
\text { sociability }\end{array}$ & \\
\hline EAS-C-Shy & $\begin{array}{l}\text { patients' temperamental } \\
\text { dispositions understood } \\
\text { as inherited personality traits: } \\
\text { shyness }\end{array}$ & \\
\hline SPR A & $\begin{array}{l}\text { measurement of the level } \\
\text { of the following parental } \\
\text { attitudes towards the child: } \\
\text { acceptance-rejection }\end{array}$ & \multirow{5}{*}{$\begin{array}{l}\text { for each } \\
\text { of the subscales, } \\
\text { the result may be } \\
\text { a value of } 10-50 \text {, } \\
\text { the higher it is, } \\
\text { the higher } \\
\text { the severity } \\
\text { of the measured } \\
\text { characteristics }\end{array}$} \\
\hline SPRR & $\begin{array}{l}\text { measurement of the level } \\
\text { of the following parental } \\
\text { attitudes towards the child: } \\
\text { the severity of requirements } \\
\text { imposed on the child }\end{array}$ & \\
\hline SPR Aut & $\begin{array}{l}\text { measurement of the level } \\
\text { of the following parental attitudes } \\
\text { towards the child: autonomy }\end{array}$ & \\
\hline SPRI & $\begin{array}{l}\text { measurement of the level } \\
\text { of the following parental } \\
\text { attitudes towards the child: } \\
\text { inconsistency }\end{array}$ & \\
\hline SPR P & $\begin{array}{l}\text { measurement of the level } \\
\text { of the following parental } \\
\text { attitudes towards the child: } \\
\text { excessive protection }\end{array}$ & \\
\hline
\end{tabular}

Based on an analysis of the literature, psychological variables that may be predictors of the level of cooperation of patients and their parents during treatment were selected..$^{8-12}$

To investigate the patients' temperamental dispositions, understood as inherited personality traits, the EAS-C Temperament Questionnaire, version for children assessed by their parents, was used. ${ }^{13}$ The A. H. Buss and R. Plomin EAS Temperament Survey provided the theoretical basis for the questionnaire. ${ }^{14,15}$

The caregivers' involvement in helping the child adhere to the recommended treatment regimen was evaluated with a questionnaire specially designed for this purpose. To investigate the caregivers' temperamental dispositions and their parental attitudes, the following standardized measurement instruments were used:

- GSES (Generalized Self-Efficacy Scale) - a tool commonly used in the study of the relationship between a sense of self-efficacy and taking various health behaviors. It shows a well-validated correlation between the level of pro-health behavior of an individual and forming health-related habits;

- NEO-FFI Personality Inventory (NEO-Five Factor Inventory) - which allows for reliable measurement of the 5 main features described in the model of personality by Costa and $\mathrm{McCrae}$. It has frequently been applied to examine the relationship between personality traits and adopting healthy behavior and the level of cooperation of the patient with the doctor. ${ }^{16}$ It displays conscientiousness: a tendency to be organized and dependable, showing self-discipline, acting dutifully and being aimed for achievement;

Table 2. Average daily wear time

\begin{tabular}{|c|c|c|c|}
\hline Patient no. & $\begin{array}{l}\text { Average daily } \\
\text { wearing time }\end{array}$ & Patient no. & $\begin{array}{l}\text { Average daily } \\
\text { wearing time }\end{array}$ \\
\hline 1 & 7.45 & 20 & 4.40 \\
\hline 2 & 7.40 & 21 & 6.25 \\
\hline 3 & 4.95 & 22 & 9.00 \\
\hline 4 & 6.80 & 23 & 7.00 \\
\hline 5 & 4.30 & 24 & 7.50 \\
\hline 6 & 10.00 & 25 & 5.75 \\
\hline 7 & 8.40 & 26 & 9.20 \\
\hline 8 & 7.44 & 27 & 6.26 \\
\hline 9 & 4.37 & 28 & 9.40 \\
\hline 10 & 8.05 & 29 & 7.12 \\
\hline 11 & 5.18 & 30 & 7.80 \\
\hline 12 & 7.75 & 31 & 5.40 \\
\hline 13 & 6.65 & 32 & 8.07 \\
\hline 14 & 7.95 & 33 & 8.31 \\
\hline 15 & 15.00 & 34 & 8.05 \\
\hline 16 & 11.15 & 35 & 9.45 \\
\hline 17 & 9.20 & 36 & 10.73 \\
\hline 18 & 9.70 & 37 & 8.17 \\
\hline 19 & 1.38 & 38 & 13.72 \\
\hline
\end{tabular}


- Parental Attitude Scale developed by Plopa - which allows for reliable measurement of the relevant characteristics of parental attitudes, expressed in parental behavior. It has previously been repeatedly used to study the relationship between the attitude toward the child and parent variables such as the level of motivation of the child's social skills, and health. ${ }^{17}$ It displays the severity of requirements imposed on the child the level of excessive requirements imposed on a child increases the degree of subordination of the child (the patient) to medical recommendations.

In order to assess patient cooperation objectively, electronic sensors (TheraMon ${ }^{\circledR}$ ) were mounted in all removable appliances. TheraMon is a new microelectronic temperature sensor system. It enables an objective and reliable measurement of wear time of a removable appliance. The microsensor is only visually perceptible and had no effect on the patient's perceived comfort when wearing the orthodontic device. The TheraMon system is also resistant to attempts of manipulation by the patient, and allows the identification of such behavior. As proved, the data received is fully reliable, and it is possible to assess the length of time during which the appliance is in the patient's mouth to an accuracy of 15 min. ${ }^{4}$ At check-up appointments, the data stored in the microsensor can be read, using a TheraMon read-out device connected with a PC via a USB interface. Measurements were carried out and read every 6 weeks for 9 consecutive

Table 3. Statistical power determined for the test of significance of Pearson's r coefficient

\begin{tabular}{|c|c|c|c|}
\hline $\begin{array}{l}\text { Daily removable } \\
\text { appliance wear } \\
\text { time and: }\end{array}$ & Power & $\begin{array}{c}\mathrm{N}_{\text {sig }} \text { (significance } \\
\text { power }=0.9)\end{array}$ & $\begin{array}{l}\text { * }- \text { test } \\
\text { confirmed } \\
\text { with power } \\
\text { analysis }\end{array}$ \\
\hline GSES & 0.923 & 36 & * \\
\hline Neo-FFI N & 0.820 & 49 & \\
\hline Neo-FFIE & 0.117 & 653 & \\
\hline Neo-FFIO & 0.082 & 1331 & \\
\hline Neo-FFI A & 0.063 & 3260 & \\
\hline Neo-FFIC & 1.000 & 15 & * \\
\hline EAS-C-Emo & 0.951 & 32 & * \\
\hline EAS-C-Act & 0.733 & 60 & \\
\hline EAS-C-SOC & 0.283 & 198 & \\
\hline EAS-C-Shy & 0.058 & 5209 & \\
\hline SPR A & 0.752 & 57 & \\
\hline SPR R & 0.982 & 25 & * \\
\hline SPR Aut & 0.784 & 54 & \\
\hline SPRI & 0.761 & 57 & \\
\hline SPR P & 0.109 & 740 & \\
\hline
\end{tabular}

$\mathrm{N}_{\text {sig }}$ - sample size needed to achieve statistical significance with the significance level $p=0.05$ and statistical power equal to 0.9; * statistically significant results ( $p<0.05)$; bold - variables, in which case normal distribution was rejected. months. The patients were instructed to wear the appliances at night (for at least $10 \mathrm{~h}$ ) and during the day (for at least $2-4 \mathrm{~h}$ ), so that the minimal wear time in total was at least $12 \mathrm{~h}$.

The correlation between personality traits and the patients' cooperation was statistically tested. Statistical calculations were made using STATISTICA v. 12.0 software (StatSoft, Inc., Tulsa, USA). In addition, in order to verify the assumption about bivariate normal distribution, the R Package mvnormtest and the MVN were used. ${ }^{18-22}$ Due to the assumption of 2-dimensional normal distribution in the test of significance of Pearson correlation coefficient, for each considered pair of variables, normality tests were performed. For each variable, the Shapiro-Wilk test was made separately. In the next step, the linear correlation was checked using the Pearson's $r$ coefficient. Statistical significance was established at $\mathrm{p}<0.05$.

All parents and caregivers signed an informed consent for participation in the study, which obtained the approval of the Ethical Review Committee no. KB-322/2014.

\section{Results}

The results consisted of primary and secondary outcomes. The primary outcome revealed that the average

Table 4. Normality test results (statistically significant result achieved in the case of one or the other test means that the hypothesis of 2-dimensional normal distribution was rejected)

\begin{tabular}{|c|c|c|c|c|}
\hline \multirow{3}{*}{ Variable } & \multicolumn{4}{|c|}{ Shapiro-Wilk } \\
\hline & \multicolumn{2}{|c|}{ 1-dimensional } & \multicolumn{2}{|c|}{ multidimensional } \\
\hline & SW & $\mathrm{p}$-value & SW & $p$-value \\
\hline $\begin{array}{l}\text { Daily removable } \\
\text { appliance wear } \\
\text { time }\end{array}$ & 0.959 & 0.1777 & & \\
\hline GSES & 0.941 & $0.0442^{*}$ & 0.945 & 0.0621 \\
\hline Neo-FFI N & 0.906 & $0.0037^{*}$ & 0.960 & 0.1935 \\
\hline Neo-FFI E & 0.895 & $0.0019^{*}$ & 0.961 & 0.2049 \\
\hline Neo-FFIO & 0.979 & 0.6946 & 0.960 & 0.1840 \\
\hline Neo-FFI A & 0.963 & 0.2401 & 0.972 & 0.4347 \\
\hline Neo-FFI C & 0.946 & 0.0650 & 0.930 & $0.0207^{*}$ \\
\hline EAS-C-Emo & 0.952 & 0.1075 & 0.837 & $0.0001^{*}$ \\
\hline EAS-C-Act & 0.937 & $0.0339^{*}$ & 0.966 & 0.2925 \\
\hline EAS-C-SOC & 0.956 & 0.1434 & 0.961 & 0.2103 \\
\hline EAS-C-Shy & 0.917 & $0.0082^{*}$ & 0.948 & 0.0742 \\
\hline SPR A & 0.917 & $0.0081^{*}$ & 0.959 & 0.1746 \\
\hline SPR R & 0.959 & 0.1731 & 0.939 & $0.0383^{*}$ \\
\hline SPR Aut & 0.897 & $0.0022^{*}$ & 0.905 & $0.0035^{*}$ \\
\hline SPR I & 0.928 & $0.0168^{*}$ & 0.934 & $0.0263^{*}$ \\
\hline SPR P & 0.973 & 0.4804 & 0.963 & 0.2407 \\
\hline
\end{tabular}

* statistically significant results ( $<<0.05)$; bold - data in which at least 1 test gave a statistically significant result. 
daily wearing time (6.09 h/day) was generally shorter compared to the instructions given to the patients. The shortest average daily wearing time was $1.38 \mathrm{~h} /$ day and the longest was $15.00 \mathrm{~h} /$ day (Table 2). As for the secondary outcome - assessing the correlations between specific psychological test results of patients and their caregivers and average daily wearing time of the removable appliances - the power analysis of the statistical tests resulted in a rejection of some measurements (Table 3 ), but it should be noted that all of the tests, for which the coefficients of correlation were high or very high, met the assumptions of the test power analysis (Tables 4-6).

\section{Discussion}

Statistical analysis showed a strong positive correlation between removable appliance wear time and the measurement results of the GSES and the SPR-R $(0.5<\mathrm{r}<0.7)$, and NEO-FFI-C $(0.7<\mathrm{r}<0.9)$. The correlation between removable appliance wear time and the EAS-C-Emo measurement results was strongly negative $(-0.5>\mathrm{r}>0.7)$ (Tables 3-6). Such results fully confirmed the assumptions that some personality traits of patients and their parents may significantly influence the compliance during orthodontic treatment. Namely, the emotionality of the child (negatively correlating with the degree of cooperation) as well as the severity of the requirements imposed on the child, a sense of self-efficacy and conscientiousness of the parents (all correlating positively with

Table 5. Correlations of psychological variables with daily appliance-wearing time

\begin{tabular}{|c|c|c|c|}
\hline \multirow{2}{*}{$\begin{array}{l}\text { Daily removable } \\
\text { appliance wear } \\
\text { time and: }\end{array}$} & \multicolumn{3}{|c|}{ Pearson's } \\
\hline & $\begin{array}{l}\text { correlation } \\
\text { coefficient r }\end{array}$ & $\begin{array}{l}\text { statistics } \\
\text { value t }\end{array}$ & $p$-value \\
\hline GSES & $\underline{0.511}$ & $\underline{3.568}$ & $\underline{0.0010^{*}}$ \\
\hline Neo-FFI N & -0.446 & -2.989 & $0.0050 *$ \\
\hline Neo-FFI E & 0.126 & 0.765 & 0.4494 \\
\hline Neo-FFIO & -0.089 & -0.535 & 0.5962 \\
\hline Neo-FFI A & -0.057 & -0.341 & 0.7351 \\
\hline Neo-FFIC & $\underline{0.721}$ & 6.242 & $\underline{0.0000^{*}}$ \\
\hline EAS-C-Emo & $\underline{-0.540}$ & $\underline{-3.845}$ & $\underline{0.0005^{*}}$ \\
\hline EAS-C-Act & -0.406 & -2.664 & $0.0115^{*}$ \\
\hline EAS-C-SOC & -0.228 & -1.405 & 0.1685 \\
\hline EAS-C-Shy & -0.045 & -0.270 & 0.7890 \\
\hline SPR A & 0.414 & 2.728 & $0.0098^{*}$ \\
\hline SPR R & $\underline{0.591}$ & $\underline{4.400}$ & $\underline{0.0001^{*}}$ \\
\hline SPR Aut & -0.428 & -2.842 & $0.0073^{*}$ \\
\hline SPR I & -0.418 & -2.759 & 0.0091 * \\
\hline SPRP & -0.119 & -0.718 & 0.4771 \\
\hline
\end{tabular}

* statistically significant results $(p<0.05)$; bold - variables, in which case normal distribution was rejected; bold and underlined - the results in which statistical power was confirmed. patient cooperation). Functional appliances are used for growth modification in orthodontic treatment, however after appropriate modifications they widen and correct the maxillary transversal dimension. The most frequently applied type of such an appliance is the twin block, also used as the only functional device in this study, in order to minimize the impact of appliance-related factors on the degree of patient compliance. ${ }^{4-7,23,24}$

Our study included patients aged 9-12 years. This age range may raise doubts as far as the ideal timing of orthodontic correction because at least part of the treated patients were before the pubertal spurt. According to a study by Bacetti et al., orthodontic treatment with twin block during the pubertal spurt is statistically more effective in overjet correction than early, pre-pubertal treatment. ${ }^{24}$ It seems therefore that pre-pubertal treatment is actually not ineffective, but it simply affects only a part of the stomatognathic system to a lesser extent. It should nevertheless be said that we did not intend to analyze the effectiveness of orthodontic treatment dependent on its timing, but only the factors affecting the level of patient compliance. It must be kept in mind that some of our patients were treated with Schwarz appliances, and interceptive treatment and early expansion of the jaw should, by definition, be carried out at the age of 9-11 years, before the pubertal growth spurt. ${ }^{7,23}$

Hönn et al. and Evans have pointed out that the level of patient compliance during treatment with removable appliances may be the "hidden" factor, without which any discussion about the effectiveness of early orthodontic treatment, especially by growth modification, makes no sense. ${ }^{5,6}$ At the same time, in many studies this aspect is either completely neglected when discussing therapeutic results, or dismissed with the laconic statement "good or bad". ${ }^{23,24}$ Therefore, based on the studies undertaken in recent years, it might be only very cautiously concluded that adult patients are more truthful than children and adolescents when reporting the appliance wear time to their doctors. According to some authors, adherence to the doctor's orders in younger patients may largely depend on parental control and the parental approach to orthodontic treatment. ${ }^{4,8,25-27}$ Such a statement has been fully supported by the results achieved in this study. The degree of patient cooperation demonstrated a strong

Table 6. Variables affecting the expected daily removable appliance wear time

\begin{tabular}{|c|c|c|c|}
\hline \multirow{2}{*}{$\begin{array}{c}\text { Daily removable } \\
\text { appliance wear } \\
\text { time and: }\end{array}$} & $\begin{array}{c}|c| \\
\text { correlation } \\
\text { coefficient } r\end{array}$ & $\begin{array}{c}\text { Pearson's } \\
\text { valistics }\end{array}$ & p-value \\
\hline GSES & 0.511 & 3.568 & $0.0010^{*}$ \\
\hline Neo-FFI C & 0.721 & 6.242 & $0.0000^{*}$ \\
\hline EAS-C-Emo & -0.540 & -3.845 & $0.0005^{*}$ \\
\hline SPR R & 0.591 & 4.400 & $0.0001^{*}$ \\
\hline
\end{tabular}

* statistically significant results $(p<0.05)$. 
or very strong correlation with the 3 characteristics of their caregivers (GSES, SPR-R and NEO-FFI-C) and with only 1 feature of children (EAS-C-Emo).

Many published studies suggest the role of selected personality characteristics of patients, including children's and young individuals' level of cooperation with the clinician. This also applies to orthodontic therapy. ${ }^{12,28}$ In fact, based on numerous studies and empirical data indicating the role of the personality traits of the parents and their parenting style in their children's health behaviors, it is assumed that these traits and attitudes toward education may also be important for monitoring the effectiveness of orthodontic therapy. ${ }^{29,30}$ Moreover, self-efficacy, a term derived from social learning theory, understood as the belief that one is able to accomplish the established goals, is a variable whose critical role in forming health behavior and cooperation in the treatment of diseases has been amply demonstrated empirically. ${ }^{15}$ Earlier studies on the determinants of the effectiveness of the therapy and prevention of dental diseases in children indicate the importance of the self-efficacy beliefs of the parents and their level of self-esteem in monitoring their children's health behaviors. ${ }^{12,31,32}$ This study showed that a sense of self-efficacy is also of great importance in the effectiveness of orthodontic treatment of children and adolescents.

In order to determine some of the caregivers' personality traits relevant to healthy behavior, we have chosen standardized, psychological tools, with proven accuracy and reliability, used many times previously in scientific research, including the study of various problems in the field of pro-health psychology. ${ }^{17,31,33-36}$ However, in the case of the patients themselves, one problem might have been their young age, which didn't allow them to fill in the study questionnaire themselves. Because of that, using the EAS-C Temperament Questionnaire, which allows for data about the characteristics of their personality from their parents, is fully justified. Oniszczenko showed that this tool is also appropriate for the age group studied due to the fact that it measures personality traits that have a strong hereditary component and already manifest themselves in behavior in the early stages of child development. ${ }^{13}$

The results of our study seem to be promising due to the following issues. Firstly, they may affect the planning and conducting of scientific research on the treatment of malocclusions using removable appliances. We showed that generally patients wear appliances much less than recommended. We also proved that the degree of compliance can be quite accurately predicted based on a study of the personality traits and attitudes of the children and parents with the use of self-descriptive psychological questionnaires. It may be considered that such results undermine the purposefulness of the current discussions about the effectiveness of orthodontic treatment, or at least underestimate the significance of stu- dies thereon. Should this be the case, the following may always be added: "with uncontrolled level of compliance". At the same time, however, they bring hope that in the future such studies will be planned much more precisely. In other words, a personality inventory for children and their parents, and a system of monitoring the daily removable appliance wear time objectively will become a sine qua non condition in efficient orthodontic treatment.

Developing a simple system for predicting the degree of patient compliance before the beginning of treatment with a removable appliance is important from the clinical point of view. The use of research instruments developed in cooperation with a psychologist to measure the patients' and caregivers' dispositions may be useful when it comes to deciding whether to attempt orthodontic or early malocclusion treatment or to postpone the therapy and implement an alternative treatment option (e.g., camouflage) at a later age. Another purpose in the area of clinical practice may be to design a support program for parents experiencing difficulties in monitoring the treatment of their children because of their temperament traits, which constitute a barrier to adherence to orthodontic recommendations. The financial aspect is also worth emphasizing: the introduction of new elements - psychological assessment and objective control of compliance - in the planning and conducting of early orthodontic treatment may help develop more effective and economical methods for treating malocclusions in children with public funds or insurance systems.

Nonetheless, we also feel obliged to list some limitations of this study. Firstly, we based an objective assessment of patient cooperation on less than 1 year of observation. However, it is currently impossible to extend the duration of the study, since there are no sensors available on the market which measure the conditions of the oral cavity for over 9 months. Secondly, although our psychological measurements may constitute a reliable tool that allows us to predict the degree of future cooperation during the orthodontic treatment, such data needs confirmation while evaluating a larger group. Such a study is already underway.

\section{Conclusions}

The cooperation of children treated with removable appliances may be predicted with a high level of probability with the observation of some patients' and their caregivers' traits. These observations may be numerically assessed and confirmed with standard psychological tests.

The presented link between the children's temperamental traits and the level of adherence constitutes a good reason to conduct qualitative research, which would make it possible to identify intermediary mechanisms (such as parents' convictions, their habitual behaviors and methods of affecting the children's behavior), which go between the parents' dispositions and the regularity of wearing 
a removable appliance by their children. This will indirectly enable the isolation of specific problems experienced during orthodontic treatment by parents of very active and emotional children. The ultimate purpose of such an extended study is to develop an instrument that would allow researchers to define the psychological factors in a potential patient and their caregiver, which predispose them to obediently follow orthodontic recommendations.

It may ultimately be concluded that, regardless of the relatively small group of patients examined, our pilot study has proved that psychological tests and new electronic systems for the objective assessment of patient cooperation may be valuable tools for a re-assessment of the paradigm of early orthodontic treatment.

\section{References}

1. Bhardwaj VK, Veeresha KL, Sharma KR. Prevalence of malocclusion and orthodontic treatment needs among 16 and 17 year-old school-going children in Shimla city, Himachal Pradesh. Indian J Dent Res. 2011;22:556-560.

2. Ciuffolo F, Manzoli L, D'Attilio M, et al. Prevalence and distribution by gender of occlusal characteristics in a sample of Italian secondary school students: A cross-sectional study. Europ J Orthod. 2005;27:601-606.

3. Proffit WR, Fields HW Jr, Moray LJ. Prevalence of malocclusion and orthodontic treatment need in the United States: Estimates from the NHANES III survey. Int J Adult Orthodon Orthognath Surg. 1998;13:97-106.

4. Schott TC, Goz G. Young patients' attitudes toward removable appliance wear times, wear-time instructions and electronic weartime measurements: Results of a questionnaire study. J Orofac Orthop. 2010;71:108-116.

5. Hönn M, Schneider C, Dietz K, Godt A, Göz G. Treating class II patients with removable plates and functional orthopaedic appliances. J Orofac Orthop. 2006;67:272-288.

6. Evans CA. Anteroposterior skeletal change: Growth modification. Semin Orthod. 2000;6:21-32.

7. Nimri K, Richardson A. Applicability of interceptive orthodontics in the community. British J Orthod. 1997;24:223-228.

8. Sergl HG, Zentner A. Predicting patient compliance in orthodontic treatment. Semin Orthod. 2000;6:231-236.

9. Berk NW. Perception of orthodontic treatment need: Opinion comparisons of orthodontists, pediatric dentists, and general practitioners. J Orthod. 2002;29:287-291.

10. Nanda RS, Kierl MJ. Prediction of cooperation in orthodontic treatment. Am J Orthod Dentofacial Orthop. 1992;102:15-21.

11. Southard KA, Tolley A, Arheart KL, Hackett-Renner CA, Southard TE. Application of the millon adolescent personality inventory in evaluating orthodontic compliance. Am J Orthod Dentofacial Orthop. 1991;100:553-561.

12. Robertson JS, Maddux JE. Compliance in pediatric orthodontic treatment: Current research and issues. CHC. 1986;15(1):40-48.

13. Oniszczenko W. Kwestionariusz temperamentu EAS Arnolda H. Bussa i Roberta Plomina. Version for adults and children. Polish adaptation. Warszawa: Psychological Test Laboratory of the Polish Psychological Association; 1997.

14. Buss AH, Plomin R. Temperament: Early Developing Personality Traits. Hillsdale, NJ: Lawrence Erlbaum; 1984.

15. Juczyński Z. Narzędzia pomiaru w promocji i psychologii zdrowia. Warszawa: Psychological Test Laboratory of the Polish Psychological Association; 2009.

16. Zawadzki B, Strelau J, Szczepaniak P, Śliwińska M. Inwentarz osobowości NEO-FFI Paula T. Costy Jr i Roberta R. McRae. Warszawa: Psychological Test Laboratory of the Polish Psychological Association; 1998

17. Plopa M. Skala postaw rodzicielskich. Version for adults. Warszawa: Psychological Test Laboratory of the Polish Psychological Association; 2008.
18. Jarek S. mvnormtest: Normality test for multivariate variables. $\mathrm{R}$ package version 0.1-9. 2012. http://CRAN.R-project.org/package = mvnormtest Accessed May 26, 2015.

19. Korkmaz S, Goksuluk D, Zararsiz G. MVN: An R package for assessing multivariate normality. The $R$ Journal. 2014;6(2):151-162.

20. Mardia KV. Measures of multivariate skewness and kurtosis with applications. Biometrika. 1970;57(3):519-530.

21. Domański C. Własności testu wielowymiarowej normalności Shapiro-Wilka i jego zastosowanie. Cracow University of Economics. Rector's Lectures. 1998;37.

22. Hotelling $H$, Pabst MR. Rank correlation and tests of significance involving no assumption of normality. Annals of Mathematical Statistics. 1936;7:29-43.

23. Dyer FMV, McKeown HF, Sandler PJ. The modified twin block appliance in the treatment of class II division 2 malocclusions. J Orthod. 2001;28:271-280.

24. Baccetti T, Franchi L, Ratner Toth L, McNamara JA Jr. Treatment timing for Twin-block therapy. Am J Orthod Dentofacial Orthop. 2000;118:159-170.

25. Romanyk DL, Lagravere MO, Toogood RW, Major PW, Carey JP. Review of maxillary expansion appliance activation methods: Engineering and clinical perspectives. J Dent Biom. 2010;1-7.

26. Jang JC, Fields HW, Vig KWL, Beck FM. Controversies in the timing of orthodontic treatment. Semin Orthod. 2005;11:112-118.

27. Press release of the "American Academy of Dental Sleep Medicine": Comparison of subjective and objective measures of oral appliance compliance during treatment of sleep-disordered breathing. Presentation date: 2011, June 11, ID: 013.

28. Smith TW, Ruiz JM. Personality theory and research in the study of health and behavior. In: Handbook of Clinical Health Psychology. Volume 3. Models and Perspectives in Health Psychology. Boll TJ, Frank RG, Baum A, Wallander JL, eds. Washington, DC: American Psychological Association; 2004:143-199.

29. Riesch SK, Anderson LS, Krueger HA. Parent-child communication processes: Preventing children's health-risk behavior. Journal for Specialists in Pediatric Nursing. 2006;11(1):41-56.

30. Zadworna-Cieślak M, Ogińska-Bulik N. Zachowania zdrowotne młodzieży - Uwarunkowania podmiotowe i rodzinne. Warszawa: Difin; 2011.

31. Lenčová E, Dušková J. Oral health attitudes and caries-preventive behaviour of Czech parents of preschool children. Acta Med Acad. 2013;42(2):209-215.

32. Albino JEN, Lawrence SD, Lopes CE, Nash LB, Tedesco LA. Cooperation of adolescents in orthodontic treatment. J Beh Med. 1991;14(1):53-70.

33. Mottus R, McNeill G, Jia X, Craig LCA, Starr JM, Deary IJ. The associations between personality, diet and body mass index in older people. Health Psychol. 2013;32(4):353-360.

34. Jerant A, Chapman B, Dupberstein P, Robbis J, Franks P. Personality and medication non-adherence among older adults enrolled in a six-year trial. British Journal of Health Psychology. 2011;16:151169.

35. Liberska H, Boniecka K. Postawy rodzicielskie rodziców dzieci otyłych i z nadwagą. Journal of Health Sciences. 2013;3(13):419-432.

36. Ryś M. Oddziaływania wychowawcze rodziców a nadzieja na sukces i kompetencje społeczne u ich dzieci. Kwartalnik Naukowy „Fides et Ratio". 201;3(7):86-108. 